\title{
Globalisation and the small economy: the case of the Netherlands
}

Citation for published version (APA):

Hogenbirk, A. E., \& Narula, R. (1999). Globalisation and the small economy: the case of the Netherlands. MERIT, Maastricht Economic Research Institute on Innovation and Technology. MERIT Research Memoranda No. 002 https://doi.org/10.26481/umamer.1999002

Document status and date:

Published: 01/01/1999

DOI:

10.26481/umamer.1999002

Document Version:

Publisher's PDF, also known as Version of record

\section{Please check the document version of this publication:}

- A submitted manuscript is the version of the article upon submission and before peer-review. There can be important differences between the submitted version and the official published version of record.

People interested in the research are advised to contact the author for the final version of the publication, or visit the DOI to the publisher's website.

- The final author version and the galley proof are versions of the publication after peer review.

- The final published version features the final layout of the paper including the volume, issue and page numbers.

Link to publication

\footnotetext{
General rights rights.

- You may freely distribute the URL identifying the publication in the public portal. please follow below link for the End User Agreement:

www.umlib.nl/taverne-license

Take down policy

If you believe that this document breaches copyright please contact us at:

repository@maastrichtuniversity.nl

providing details and we will investigate your claim.
}

Copyright and moral rights for the publications made accessible in the public portal are retained by the authors and/or other copyright owners and it is a condition of accessing publications that users recognise and abide by the legal requirements associated with these

- Users may download and print one copy of any publication from the public portal for the purpose of private study or research.

- You may not further distribute the material or use it for any profit-making activity or commercial gain

If the publication is distributed under the terms of Article $25 \mathrm{fa}$ of the Dutch Copyright Act, indicated by the "Taverne" license above, 


\title{
Globalisation and the Small Economy: The Case of the Netherlands
}

\author{
Annelies Hogenbirk \\ University of Maastricht \\ and \\ Rajneesh Narula \\ University of Oslo
}

Januari 1999

(to be published in Van Den Bulcke, D. and A. Verbeeke (1999) Globalisation and the Small Economy, Edgar Elgar, Forthcoming)

\begin{abstract}
In this paper, we have examined the importance and implications of globalisation due to FDI for one particular small country: the Netherlands. Although it has limited resources and size, the Netherlands is home to the sixth largest outward FDI stock in the world, and also is one of the most important destinations for inward FDI activity. Its location advantages are, inter alia, a function of its de facto market size, given its central location within the EU, and its well developed infrastructure. Furthermore, the growing competitiveness of the service sector in the Netherlands plays a pivotal role.

Other small economies can benefit from the Dutch experience, by investing in improving their competitiveness, since usually their activities are concentrated in only a few sectors. The need to maintain and upgrade their location advantages, by adopting new technologies and upgrading their created assets, is central to their survival.
\end{abstract}




\title{
Globalisation and the Small Economy: The Case of the Netherlands
}

\author{
Annelies Hogenbirk and Rajneesh Narula
}

\section{INTRODUCTION}

Foreign direct investment (FDI) continues to be a driving force of the globalisation process that characterises the modern world economy (UN 1997). FDI is conducted by multinational enterprises (MNEs) that organise and control an increasing proportion of world production and distribution. By 1995, 45000 parents and more than 280000 affiliates had an estimated US\$ 7 trillion sales. Total FDI stock, a measure of the investment underlying international production, has increased fourfold between 1982 and 1994, and by 1996 was valued at US\$ 3.2 trillion (UN 1997). The increasing importance of MNEs in economic development has raised concerns about the impact on small economies ${ }^{1}$. They are generally not in a very good bargaining position towards MNEs due to the lack of a large internal market and insufficient resources to attract $\mathrm{FDI}^{2}$. These same restrictions also tend to handicap the growth of domestic firms, although smaller firms from smaller countries tend to engage in relatively higher levels of international economic activity than those from larger firms to compensate for these restrictions. Inward and outward FDI are essential and complementary to good economic policy, especially in a small country. Nonetheless, globalisation has changed economic realities for firms from small countries, to some extent emphasising these handicaps, at the same time proving to be an important driving force for their economic growth.

In this paper we will examine the importance and implications of globalisation for one particular small OECD country: the Netherlands. The Netherlands is home to some of the largest MNEs in the world. Furthermore, it is an open economy and trade relations have always been important for its economic development. Being a small country lacking important resources, it is dependent on raw material imports for its production. Lacking a large internal market encourages Dutch firms to export to other countries to supply a larger market. One important characteristic of the Dutch economy is its specific location (L-) advantages, such as a well-developed infrastructure and its favourable location within Europe. The Netherlands was among the first to acknowledge the importance and potentials of European unification, being part of EEC6 in 1958. Furthermore, it has invested in creating particular assets that contribute to economic competitiveness, such as a multilingual, high-skilled labour force. Moreover, the economy is characterised by political stability and non-discriminatory fiscal policies that result in a favourable investment climate 
encouraging foreign firms to establish affiliates in the Netherlands. These same factors have also played a significant role in the continued competitiveness of Dutch MNEs.

This chapter provides a critical assessment of the effects of globalisation on the Netherlands. First of all, the importance of MNEs in the process of globalisation is discussed. After that, we consider how the developments related to globalisation has affected the Netherlands. Following a general examination of economic developments such as growth and trade patterns, geographical and sectoral patterns in the investment behaviour of both Dutch MNEs and MNE-subsidiaries operating in the Netherlands are discussed. Some conclusions and implications for small economies in general are given at the end.

\section{GLOBALISATION AND MNE ACTIVITY}

Globalisation as a term is much abused both in the popular and academic press. Globalisation as used here will refer to economic globalisation, which we will define as the increasing cross-border interdependence and integration of production and markets for goods, services, and capital. This process leads both to a widening of the extent and form of international transactions, and to a deepening of the interdependence between the actions of economic actors located in one country and those located in other countries (Narula and Dunning 1998). It is perhaps best demonstrated by the huge increases in the transnational flows of both portfolio and direct investment, and in the number of cross-border strategic alliances.

The increasing importance of MNEs in the world economy is a central feature of globalisation, not just because large firms have increased their international presence, but because numerous smaller firms have, due to the factors underlying globalisation, been able to expand their operations internationally. These developments include the changes associated with ${ }^{3}$ :

(i) the rapid development of new technologies, and the consequential reduction in cross-border communication and organisational costs. These technologies have, in certain instances, increased the costs of innovation and the rapidity of technological change. As such, firms are obliged to seek larger markets, either individually or in partnership with other firms, as a means to reduce the risks and costs through economies of scale. At the same time, though, there have been cases where new technologies have allowed for a reduction in the minimum efficient scale. The lowered costs of information and communication have also allowed a large number of smaller firms with limited resources to internationalise their operations.

(ii) the renaissance of democratic capitalism and the liberalisation of many domestic and international markets (which has resulted in the opening up of new sales and production markets), accompanied by an ideological shift towards reduced government intervention. 
Since most governments have been unable to slow down the increasing economic liberalisation of countries due to exogenous change, this has significantly affected their competitiveness. Thus MNEs are able to enter new markets and new sectors in countries which were hitherto closed to foreign-owned firms. On the other hand, former state-owned enterprises that were privatised are now free to compete in overseas markets for capital and markets.

Studying MNE activity is fraught with complications which can be broadly classified into two headings. First, studying MNE activity is difficult because of the broad range of activity that MNEs engage in. Transactions and forms of activity range from spot transactions and intra-firm trade to strategic alliances, joint ventures and wholly owned subsidiaries. Secondly, the difficulty is further enhanced by the problems in measuring this activity. Government and supra-national agencies rarely record MNE transactions separately from other transactions, and even where they do so, the definitions, quality, and detail of data varies from one country to another. As such it is essential to highlight that data used here is primarily a means to illustrate trends and relative differences between and amongst countries. In general, data is most reliable on the foreign direct investment activity (FDI) of MNEs, and we utilise this here as a rough measure.

Regardless of these limitations, the data is quite unambiguous about the significance of MNE activity. Table 1 gives details of the FDI activities of 6 EU countries (Germany, France, United Kingdom (UK), the Netherlands, Italy, and Sweden) as well as Norway, Japan and the US. These 6 EU-countries account for almost $40 \%$ of all outward FDI (OFDI) worldwide in 1995, and this share has been increasing. Indeed, these 6 EU-countries account for about $80 \%$ of all OFDI from Europe, with a large share of the remainder being conducted by Swiss MNEs. Interestingly, these same 6 countries account for about the same level of inward FDI (IFDI) - about 30\% of total worldwide FDI stock in 1995. These figures represent historical cost values of stock, which are widely regarded as a good (monotonic) proxy for sales. If one takes the sum of IFDI and OFDI as a percentage of GDP, the data would suggest that the sales of foreign MNE affiliates and domestic MNEs accounted for at least a quarter of the GNP of the EU in 1995. Including knock-on effects due to suppliers, non-FDI transactions such as licensing, etc., this figure would most likely double.

Although data regarding the significance of intra-firm trade and MNE-related trade is somewhat sporadically available, we can get an idea of its significance from examining data for the US. In terms of domestic MNE activity in the US, MNEs accounted for 58\% of all exports and 41\% of all imports in 1992 (Narula 1996a). When we examine the trade undertaken by US affiliates of foreign MNEs, these account for $23 \%$ of exports and $37 \%$ of imports, suggesting that $81 \%$ of all US merchandise exports and $77 \%$ of imports is by, through or to MNEs. In terms of intra-firm trade, $37.2 \%$ of all US exports are intra-firm, and $42.5 \%$ of all US imports. In most of the major European economies, it can safely be argued, MNE and intra-firm trade have 
at least this level of significance: that is to say, at least about a quarter of all trade within the OECD countries is intra-MNE in nature, and at least half of world trade is conducted by, from and to MNEs.

Table 1

FDI activity from and by selected OECD countries $1980,1992 \& 1995$

\begin{tabular}{|c|c|c|c|c|c|c|c|c|c|c|c|c|c|c|c|c|c|c|}
\hline \multirow[b]{2}{*}{$\begin{array}{l}\text { Coun- } \\
\text { try/ } \\
\text { Area }\end{array}$} & \multicolumn{6}{|c|}{1980} & \multicolumn{6}{|c|}{1992} & \multicolumn{6}{|c|}{1995} \\
\hline & $\begin{array}{l}\text { OFDI } \\
\text { Stock }\end{array}$ & $\begin{array}{l}\% \\
\text { of } \\
\text { total }\end{array}$ & $\begin{array}{l}\text { IFDI } \\
\text { Stock }\end{array}$ & $\begin{array}{l}\% \\
\text { of } \\
\text { total }\end{array}$ & $\begin{array}{c}\text { country } \\
\text { share } \\
\text { of } \\
\text { world } \\
\text { GDP }\end{array}$ & $\begin{array}{c}\text { MNE } \\
\text { share } \\
\text { of } \\
\text { GDP }\end{array}$ & $\begin{array}{l}\text { OFDI } \\
\text { Stock }\end{array}$ & $\begin{array}{l}\% \\
\text { Of } \\
\text { Total }\end{array}$ & $\begin{array}{l}\text { IFDI } \\
\text { Stock }\end{array}$ & $\begin{array}{l}\% \\
\text { of } \\
\text { total }\end{array}$ & $\begin{array}{c}\text { country } \\
\text { share } \\
\text { of } \\
\text { world } \\
\text { GDP }\end{array}$ & $\begin{array}{c}\text { MNE } \\
\text { share } \\
\text { of } \\
\text { GDP }\end{array}$ & $\begin{array}{l}\text { OFDI } \\
\text { Stock }\end{array}$ & $\begin{array}{l}\% \\
\text { of } \\
\text { total }\end{array}$ & $\begin{array}{l}\text { IFDI } \\
\text { Stock }\end{array}$ & $\begin{array}{l}\% \\
\text { of } \\
\text { total }\end{array}$ & $\begin{array}{c}\text { country } \\
\text { share } \\
\text { of } \\
\text { world } \\
\text { GDP }\end{array}$ & $\begin{array}{c}\text { MNE } \\
\text { share } \\
\text { of } \\
\text { GDP }\end{array}$ \\
\hline $\begin{array}{l}\text { W- } \\
\text { Europe }\end{array}$ & 236579 & 45.6 & 200287 & 41.8 & 23.4 & 17.3 & 999852 & 51.7 & 838316 & 43.1 & 34.5 & 23.1 & 1395195 & 49.6 & 1192155 & 41.6 & 35.7 & 26.0 \\
\hline G & 43127 & 8.3 & 36630 & 7.6 & 7.3 & 10.1 & 178682 & 9.2 & 129606 & 6.7 & 7.8 & 17.2 & 259746 & 9.2 & 167137 & 5.8 & 8.7 & 17.7 \\
\hline $\mathrm{F}$ & 23604 & 4.5 & 22617 & 4.7 & 6.2 & 7.0 & 160897 & 8.3 & 119198 & 6.1 & 5.7 & 21.2 & 181255 & 6.4 & 147623 & 5.2 & 5.5 & 21.4 \\
\hline UK & 80434 & 15.5 & 63014 & 13.2 & 5.0 & 26.7 & 221197 & 11.4 & 173254 & 8.9 & 3.9 & 43.7 & 302847 & 10.8 & 314650 & 11.0 & 4.0 & 55.8 \\
\hline $\mathrm{N}$ & 42116 & 8.1 & 19167 & 4.0 & 1.6 & 35.7 & 131730 & 6.8 & 83733 & 4.3 & 1.4 & 67.3 & 164754 & 5.9 & 112336 & 3.9 & 1.4 & 70.0 \\
\hline I & 7319 & 1.4 & 8892 & 1.9 & 4.2 & 3.6 & 68718 & 3.6 & 62740 & 3.2 & 5.3 & 10.7 & 97042 & 3.5 & 63455 & 2.2 & 3.9 & 14.8 \\
\hline$S$ & 5611 & 1.1 & 3626 & 0.8 & 1.2 & 7.4 & 50547 & 2.6 & 14199 & 0.7 & 1.0 & 29.3 & 71491 & 2.5 & 36521 & 1.3 & 0.8 & 47.2 \\
\hline $\mathrm{N}$ & 1944 & 0.4 & 6699 & 1.4 & 0.6 & 13.7 & 12319 & 0.6 & 8484 & 0.4 & 0.5 & 18.4 & 22519 & 0.8 & 19652 & 0.7 & 0.5 & 28.9 \\
\hline Total & 204155 & 39.3 & 160645 & 33.5 & 26.0 & 13.0 & 824090 & 42.6 & 591214 & 30.4 & 25.5 & 24.0 & 1099654 & 39.1 & 861374 & 30.1 & 24.8 & 28.4 \\
\hline Japan & 18833 & 3.6 & 3270 & 0.7 & 9.8 & 2.1 & 250430 & 13.0 & 38720 & 2.0 & 15.9 & 7.9 & 306769 & 10.9 & 17814 & 0.6 & 18.3 & 6.4 \\
\hline USA & 220178 & 42.4 & 83046 & 17.3 & 25.1 & 11.2 & 488767 & 25.3 & 419526 & 21.6 & 25.7 & 15.3 & 709200 & 25.2 & 560088 & 19.5 & 25.0 & 18.3 \\
\hline $\begin{array}{l}\text { Other } \\
\text { devel. }\end{array}$ & 64314 & 12.4 & 125896 & 26.3 & 11.0 & 16.0 & 306329 & 15.9 & 470684 & 24.2 & 12.3 & 27.4 & 462022 & 16.4 & 602782 & 21.0 & 12.6 & 30.3 \\
\hline $\begin{array}{l}\text { Total } \\
\text { devel. }\end{array}$ & 507480 & 97.8 & 372857 & 77.8 & 72.0 & 11.3 & 1869616 & 96.8 & 1520144 & 78.2 & 79.4 & 18.5 & 2577645 & 91.7 & 2042058 & 71.3 & 80.7 & 20.5 \\
\hline $\begin{array}{l}\text { Deve- } \\
\text { loping }\end{array}$ & 11310 & & 106241 & 22.2 & 28.0 & 3.9 & 62418 & 3.2 & 420194 & 21.6 & 20.6 & 10.2 & 231405 & 8.2 & 789743 & 27.6 & 19.3 & 19.0 \\
\hline Total & 518869 & 100 & 479175 & 100 & 100 & 9.3 & 1932300 & 100 & 1945104 & 100 & 100 & 16.8 & 2811007 & 100 & 2865839 & 100 & 100 & 20.4 \\
\hline
\end{tabular}

Source: UN (1995, 1997), World Bank (1994,

1997)

$\mathrm{G}=$ Germany, $\mathrm{UK}=$ United Kingdom, $\mathrm{NL}=$ Netherlands, $\mathrm{F}=$ France, $\mathrm{S}=$ Sweden, N= Norway,

I=Italy

The importance of MNEs in economic activity has resulted in fierce competition for FDI among countries. Countries that are large recipients of MNE activities can benefit from the effects on production and employment, both directly by the MNE and also indirectly by the increased or changed activities of the suppliers and competitors of those MNEs. FDI may also provide resources and capabilities otherwise unattainable that can result in an upgrade of their indigenous resources and capabilities. Up to the beginning of the 1980s, government policies could effectively act to increase some of the country's L-advantages, for instance by increasing the incentives and/or the constraints on firms to resort to FDI. However, the 
increasing competition for FDI has made these efforts less effective. Furthermore, MNEs have now considerably more choice in terms of locations, increasing the pressure on governments to upgrade their location advantages and in some instances, offer increased incentives, thereby reducing the net benefits that accrue to countries (Narula and Dunning 1998).

Although the possibilities to attract FDI have reduced for individual countries, trends towards regionalisation have resulted in increased interest by MNEs in particular regions. One of the primary advantages of European integration has been the creation of a single 'bloc' due to economic and political initiatives resulting in an enlarged market, with considerable opportunities to achieve economies of scale. The elimination of all intra-EU tariff barriers (Mark I integration) has enabled foreign owned firms to engage in product and process specialisation in particular countries in the EU, and to supply other European markets from there. Furthermore, the opportunity to circumvent the trade restrictions between the EU and the rest of the world has proven to be an important incentive to investment within the EU (Bouma 1996). Europe is the first pole of the Triad both for the origin and the destination of FDI (Chesnais and Sailleau 1997). The Single European Market initiative triggered considerable investments to Europe from the US, Canada, and Japan. Dunning (1992) emphasises that the challenges of 1992 and the fear of a "Fortress Europe" have led to a revitalisation of US investment in the EU. EFTA countries have tried to establish a more solid base in the EU as well.

Furthermore, the enlarged market due to the completion of the internal market has led to a restructuring of intra-EU investments as well. Integration helps lower costs of production and reduces cross-border transport costs and can lead to increased demand. Furthermore, integration may lead to intra-regional product and process specialisation, make further economies of scale possible, and enable multi-product firms to exploit fresh economies of scope (Dunning 1992). Many companies have also tried to strengthen their position on an integrated market via mergers and acquisitions (Bouma 1996).

From a MNE perspective, globalisation has considerably influenced the nature of the core competencies of firms. These competencies have become increasingly mobile, firm-specific, and knowledge-intensive. MNEs have sought to identify and use their Ownership- $(\mathrm{O})$ advantages in conjunction with the immobile created assets that are location and country-specific (Narula and Dunning 1998). Porter (1994) emphasises that firms can now source factors such as raw materials, capital, and even generic scientific knowledge in many markets, and locate selective activities overseas to tap into low-cost inputs. Home market volume is less important than the ability to reach global markets. Advancing technology has given firms the ability to eliminate, nullify, or circumvent weaknesses in local factors. New technology is also diminishing economies of scale in certain industries, and/or allowing them to be rapidly neutralised by smaller but more competitive 
rivals. The basis for competitive advantage has shifted from static efficiencies to the rate of dynamic improvement.

\section{GLOBALISATION AND SMALL ECONOMIES}

As highlighted by numerous studies small open economies share certain features (see for example Freeman and Lundvall [eds.] 1988, Dunning and Narula [eds.] 1996, Tulder 1999, Hoesel and Narula 1999, Bellak and Cantwell 1998). This body of literature has illustrated that small open economies tend to be more internationalised, with a relatively large share of the value-added activity being conducted with the explicit purpose of serving overseas markets. Furthermore, firms from these countries tend to be competitive in a few niche sectors, as small countries tend to have limited resources and prefer to engage in activities in a few targeted sectors, rather than spreading these resources thinly across several industries.

Table 2 reports data on basic economic indicators for several European countries. Small economies (in population size and GDP) such as the Netherlands, Switzerland, Belgium, and Sweden are much more internationalised on a relative basis (looking at the importance of trade in their economies) than their larger counterparts such as Germany, France, and the UK, as is well illustrated by this table.

Some of the characteristics of small economies are a function of size per se. The demand conditions restrain the sectors and kind of ownership advantages that firms of a particular nationality develop. Small market size constitutes a disadvantage in the development of process technology as the economies of scale are not present, but may provide a competitive advantage in product innovation (Walsh 1988). This applies to the

kind of created asset location advantages small countries can provide ${ }^{4}$ - they have less resources ${ }^{5}$, and must either spread resources more thinly over the various disciplines, or it must select areas as priorities, and these often (but not always) are those in which they have a natural-asset advantage and lead to a specialisation of domestic firms in particular niche sectors (Soete 1987, Archibuigi and Pianta 1992, Narula 1996b). Needless to say, they tend to attract inward investment in these same sectors. On the other hand small country economies tend to be more highly internationalised, because of the limited economies of scale the home market provides, and their firms tend to be more highly internationalised, and often are involved in rationalised production due to the limited resources of their home economies.

The effects of globalisation are somewhat different for small countries than for larger countries (Bellak and Cantwell 1998). Since they are more highly internationalised they are influenced by external factors much more acutely than larger economies. First, an economic recession in a primary foreign market may play havoc with the domestic economy. This is also as a result of a second characteristic typical of small open economies. Traditionally, small country economies are dominated by a handful of large firms and numerous 
small firms. When the sales of this handful of large MNEs falls in overseas markets, the domestic knock-on effects are quite significant. Third, small country governments have limited discretion in national policy, due to their internationalised nature. Fourth, when a small country undergoes an economic restructuring, this is a much more significant and deeply felt process, because the economy tends to be focused in a few niche sectors. In larger economies, because there are more sectors, the effect of restructuring is averaged out, while in smaller economies the ramifications are much more profound.

Table 2

Basic economic indicators

1995

\begin{tabular}{|c|c|c|c|c|c|c|c|c|c|}
\hline & Germany & France & UK & Netherlands & Italy & Sweden & Switzerland & Denmark & Belgium \\
\hline Population (thousands) & 81662 & 58141 & 58613 & 15457 & 57283 & 8827 & 7081 & 5228 & 10137 \\
\hline GDP (bln US\$, PPPs) & 1673.8 & 1159.3 & 1041.9 & 305.6 & 1114.7 & 165 & 175.7 & 90.9 & 210.8 \\
\hline GDP per capita (PPPs) & 20497 & 19939 & 17776 & 19782 & 19465 & 18673 & 24809 & 21529 & 20792 \\
\hline \multicolumn{10}{|l|}{ Sectoral GDP (\%) } \\
\hline Primary & 1.3 & 0.5 & 2.2 & 4.0 & 3.4 & 3.8 & 3.4 & N.A. & 1. \\
\hline Secondary & 41.1 & 33.6 & 34.4 & 31.8 & 27.9 & 23.0 & 37.4 & N.A. & 23.8 \\
\hline Tertiary & 57.7 & 65.8 & 63.4 & 64.1 & 68.7 & 73.2 & 59.3 & N.A. & 74.2 \\
\hline \multicolumn{10}{|l|}{ Sectoral labour (\%) } \\
\hline Agriculture & 3.3 & 5.1 & 2.1 & 4.0 & 7.7 & 3.4 & 4.0 & 5.1 & 2.6 \\
\hline Industry & 37.6 & 27.8 & 27.7 & 23.0 & 32.1 & 25.0 & 28.8 & 26.8 & 27.7 \\
\hline Services & 59.1 & 67.3 & 70.2 & 73.0 & 60.2 & 71.6 & 67.3 & 68.1 & 69.7 \\
\hline $\ln$ US\$) & 523000 & 286762 & 242692 & 197087 & 233868 & 79595 & 81499 & 49045 & 170230 \\
\hline Export/C & 21.7 & 18.7 & 22.0 & 49.8 & 21.5 & 34.5 & 26.6 & 28.3 & 63.2 \\
\hline Import (ci & 463472 & 267059 & 265696 & 177912 & 206246 & 64469 & 80193 & 43728 & 155449 \\
\hline Import/GDP (\%) & 19.2 & 17.4 & 24.1 & 45.0 & 19.0 & 28.0 & 26.2 & 25.2 & 29. \\
\hline
\end{tabular}

Source: OECD Economic Surveys, various issues

N.A.= not available

\section{ECONOMIC CHARACTERISTICS OF THE NETHERLANDS}

The Kingdom of the Netherlands is a small economy, both in population size (15.5 million) and in land area (33920 sq. km). Although small in size, it is considered one of the richest nations in the world, with GDP per capita (at current prices and exchange rates) estimated at US\$ 25597 in 1995 (OECD 1996). It is favourably located on the North Sea, between Belgium and Germany. The country has developed an important position in international trade due to the world's largest harbour in Rotterdam ${ }^{6}$ and the growing importance of one of its airports: Schiphol near Amsterdam. More than $5000 \mathrm{~km}$ of waterways merge in the Netherlands making it a primary starting point for inland shipping on the rivers Rhine, Meuse, and Schelde. Its most important natural resources consist of natural gas, petroleum, and fertile soil.

The Netherlands is generally characterised as a late industrialiser that developed as a diversified economy after $1860^{7}$. The industrial development was partly dependent on trade related activities (including the 
exploitation of its colonies, especially Indonesia) and partly on labour intensive industries such as textiles and mining (which location was mainly determined by regional factors). The country was able to benefit optimally from the economic boom up to W.W.I due to its favourable location and diversified economy. Like all other economies, the Netherlands suffered from the economic recession during the 1930s and the damages due to W.W.II. However, during the years following W.W.II, the country became an attractive location for both national and international investors due to the government coalitions that emphasised the need for moderate wages and negotiated slow wage developments in close co-operation with the labour unions. Wage moderation contributed significantly to the economic recovery.

However, during the 1960s, the demand for higher wages became stronger and inflation set in. Economic decline occurred due to the oil crises in the 1970s and it takes until the mid-1980s before the economy recovered. Like most other small economies, Dutch industry includes a large number of small and mediumsized enterprises and a handful of very large multinationals (listed in Table 7). The strongest sectors include construction, (bulk) chemicals, oil refining, paper and packaging, food and beverages, and tobacco. As with other industrialised economies, the importance of the industrial sector in both GDP and employment has been declining as the Dutch economy has become more and more service oriented. As we can see from Table 2, about $73 \%$ of total workforce is currently employed within this sector, a much higher share than most other European countries such as Belgium (70\%), Switzerland (67\%), and Germany (59\%).

\section{Growth}

Table 3 takes a closer look at GDP growth and labour productivity data for the Netherlands compared to a group of 11 Northwest European countries ${ }^{8}$. We see that economic growth during the period 1960-1973 had been exceptionally large and labour productivity increased faster than in most neighbouring countries. The Dutch government emphasised the necessity for wage- and inflation control creating a favourable investment climate. In addition, there was an unprecedented growth of the world economy in general, and the resulting high profits encouraged new investments that kept production capacity up to date and encouraged further labour productivity growth. This trend was aggravated by the large capital investments that occur after W.W.II to recover from the damage caused during the war.

However, during the years following the OPEC oil crises, there was a serious decline in Dutch growth, even more so than in the other NW-European countries. This was due inter alia, to a wage explosion, the two oil shocks, and misguided policies. Inflation accelerated, output and employment growth slowed and an expansion of the welfare system. At first this expansion was financed through growing oil and gas revenues, but eventually it led to an increased tax burden, - a sort of vicious circle - which later became known as the "Dutch Disease". Real labour costs increased sharply, exceeding productivity gains; the profit position and 
international competitiveness of firms declined; real investments and net exports collapsed; house prices dived; and the Dutch economy went into a severe recession during the period 1981-82 (OECD 1998).

Table 3

Growth patterns for the Netherlands compared to those of other North-West European countries 1960-1997

\begin{tabular}{lrrrr}
\hline Period & \multicolumn{1}{c}{ GDP } & \multicolumn{2}{c}{ GDP per capita } \\
Netherlands & Northwest-Europe $^{* *}$ & Netherlands & Northwest-Europe \\
\hline $1960-73$ & 4.83 & 4.52 & 3.57 & 3.63 \\
$1973-79$ & 2.68 & 2.26 & 1.93 & 2.05 \\
$1979-87$ & 1.22 & 2.01 & 0.67 & 1.74 \\
$1987-94$ & 2.54 & 1.76 & 1.83 & 1.13 \\
$1994-97^{*}$ & 2.9 & $2.3 \#$ & & \\
\hline
\end{tabular}

Source: Van Ark and De Jong, 1996, pp. 201

$*=$ OECD 1998.

\# = EU-average calculated by OECD secretariat

** = Northwest European countries include Austria, Belgium, Denmark, Finland, France,

Germany, Netherlands, Norway, Sweden, Switzerland, and the UK

However, since that time, the Dutch economy has shown a remarkable comeback. A reorientation of the Dutch economy was initiated in 1982 - away from demand-management and towards a more supplyoriented approach, fiscal consolidation, a stable exchange rate of the guilder vis-à-vis the Deutschmark, a progressive overhaul of the social security system, and regulatory reform (usually characterised as the "Dutch model"). Wage moderation agreements between employers and trade unions contributed to the success of this new policy. The government has strongly supported this development by cutbacks in social security, reduced minimum wages and lower taxes. Due to these developments the Dutch economy has been more successful in creating (both more flexible and also part-time) jobs than most other OECD countries. The Dutch economy has also been performing rather well in terms of GDP growth. Output has expanded and inflationary pressures are only moderate. The "Dutch model" has also contributed to the increased competitiveness of the Netherlands. Currently, therefore, there is international acknowledgement of the success of the "Dutch model" (OECD 1998).

Table 4

Dutch Trade relations

1996

\begin{tabular}{|c|c|c|c|c|}
\hline \multirow[b]{2}{*}{ Country/Area } & \multirow[b]{2}{*}{ Share of total Exports } & \multirow[b]{2}{*}{ Share of total Imports } & \multicolumn{2}{|c|}{ Value (mln dfl) } \\
\hline & & & Exports & Imports \\
\hline
\end{tabular}




\begin{tabular}{lccrr} 
Europe & 86 & 71 & 287285 & 215992 \\
EU15 & 80 & 64 & 267053 & 195461 \\
France & 11 & 7 & 37023 & 22499 \\
Belgium and Luxembourg & 13 & 11 & 44057 & 34249 \\
Germany & 29 & 22 & 95698 & 68140 \\
Italy & 6 & 4 & 19723 & 10840 \\
UK & 10 & 10 & 31973 & 30506 \\
Ireland & 1 & 1 & 2350 & 3377 \\
Denmark & 2 & 1 & 5464 & 3330 \\
Greece & 1 & 0 & 2812 & 491 \\
Portugal & 1 & 1 & 2425 & 1991 \\
Spain & 3 & 2 & 9679 & 6303 \\
Sweden & 2 & 3 & 7805 & 8395 \\
Finland & 1 & 1 & 2885 & 2749 \\
Austria & 2 & 1 & 5155 & 2591 \\
Rest of Western Europe & 3 & 4 & 10630 & 12418 \\
Norway & 1 & 2 & 2157 & 6513 \\
Switzerland & 1 & 1 & 4607 & 3487 \\
Eastern Europe & 3 & 3 & 9602 & 8112 \\
US & 3 & 8 & 10683 & 24718 \\
Japan & 1 & 4 & 3440 & 10780 \\
\hline Source CBS & & & &
\end{tabular}

Source: CBS statistical yearbook, 1996

\section{Trade relations}

The competitiveness of the Netherlands (it ranked $4^{\text {th }}$ in the World Competitiveness Yearbook 1998, coming from $6^{\text {th }}$ place in 1997) has resulted in part from a favourable trading position for many years. The Netherlands has been a leading international trading centre since the $16^{\text {th }}$ century. Being a small country with limited natural resources, it has always required foreign raw materials for its production activities. Tables 2 and 4 show the importance of trade relations for the Dutch economy. The importance of exports and imports to GDP has not changed considerably since W.W.II, staying constant at about $50 \%$ and $45 \%$ respectively.

Table 2 compares some general economic characteristics of the Netherlands with those of several other European countries. As Table 2 indicates, like most other small countries, the Netherlands depends on trade relations quite heavily although even compared to other similar European economies its position is quite exceptional, with exports equivalent to about half of GDP, and slightly larger than imports that amount to around $45 \%$ in 1995. Part of this extraordinary position can be explained by the importance of the Netherlands as a distribution centre for continental Europe. A large percentage of exports actually represent 
items that will be re-exported. However, even taking these transhipments into account, its strong international orientation cannot be ignored.

Table 4 analyses the trade pattern for the Netherlands in 1996, looking at the shares of individual countries in both exports and imports. It reveals that its most important trade relations are with its neighbouring and member-EU-countries: Germany, Belgium and Luxembourg, the United Kingdom, France, and Italy. Outside Europe, the US has been a particularly important destination for imports ( $8 \%$ of total, more than twice the size of exports to the US).

Table 5 shows data on the division of Dutch exports and imports, looking at particular regions in the world, taking a longer historical perspective (1970-1995). Again we see that the Dutch economy is irrevocably tied to Europe, although this dependency has slightly decreased, as has the North American share of both imports and exports. The importance of Japan, other European countries, and the rest of the world as destinations for imports have increased significantly. The slightly decreasing importance of trade relations with other European countries is due to a substitution of trade with FDI activities. During this period both inward and outward FDI activities have increased significantly, as will be shown in the next section.

In terms of industrial distribution, the most important imports come from machinery and transportation equipment, food, beverages and tobacco, chemicals, and petroleum and related products (Central Bureau of Statistics 1995). Dutch exports primarily constitute of similar goods to its imports: machinery and transportation equipment, food, beverages and tobacco, chemicals, and scientific instruments (Central Bureau of Statistics 1995). It is important to note that these products originate in the sectors that dominate Dutch industrial production. Dutch production is rationalised by a few large MNEs: Royal Dutch/Shell, Akzo Nobel and DSM in chemicals; Unilever in food and beverages; and Philips and Oce van der Grinten in electronics. As has been mentioned in the previous section, a large share of MNE trade is intra-firm trade. This is true for the Netherlands as well.

Table 5

Trade relations of the Netherlands with the European Union and the Rest of the World

\begin{tabular}{|c|c|c|c|c|c|}
\hline Year & EU & Other Europe & USA and Canada & Japan & Rest of World \\
\hline \multicolumn{6}{|c|}{ Exports } \\
\hline 1970 & 76.6 & 3 & 4.9 & 0.7 & 13.0 \\
\hline 1980 & 76.9 & 3.2 & 2.8 & 0.4 & 15.7 \\
\hline 1990 & 75.3 & 2.5 & 3.9 & 0.8 & 16.6 \\
\hline 1995 & 71.4 & 2.4 & 3.5 & 1 & 20.8 \\
\hline \multicolumn{6}{|c|}{ Imports } \\
\hline 1970 & 67 & 1.9 & 11.1 & 1.1 & 18.2 \\
\hline 1980 & 58 & 2.7 & 9.5 & 1.9 & 27.0 \\
\hline 1990 & 67 & 2.8 & 8.4 & 3.1 & 17.7 \\
\hline
\end{tabular}


Source: United Nations, Handbook of International Trade and Development Statistics, 1995

In addition, though, unlike many other industrialised economies, the Netherlands remains highly competitive in the primary sector as can be seen from the relatively large share of all food products and agricultural raw materials in Dutch exports (23.7\% 1995, United Nations 1996). Several studies (Jacobs et. al. 1990, Jabobs and de Jong 1992, Beije and Nuys 1997, Brouthers and Brouthers 1997) have shown that particular primary commodities continue to be competitive sectors. They include cut flowers, bird's eggs in the shell, porkers, bulbous and living plants, milk cream, cacao, fresh tomatoes and potatoes, and gaseous carbons (Jacobs et.al. 1990). Porter (1990) also emphasises the Dutch strength in dairy products. Most of these products result from one particular strength: excellent grasslands.

\section{MNE ACTIVITY AND THE NETHERLANDS}

Having established the importance of MNE activity for any economy in the 1990s in one of the previous sections, we will now take a closer look at the characteristics of MNEs in the Netherlands. We will consider both outward and inward investments. Dutch Outward FDI is considerably larger than inward FDI, making the country a net-capital exporter. This is not surprising, considering the export-surplus that we have seen in the previous sections. We will use figures collected by the Dutch Central Bank (De Nederlandsche Bank, DNB $)^{10}$ and the United Nations to give an impression of the importance of MNE activity in the Netherlands.

\section{Outward FDI}

The most salient point of Dutch outward investments is their extraordinary size. It ranks $6^{\text {th }}$ in the top ten outward investors in 1996 with total outward stock of US\$ 184.7 billion (United Nations 1997), a remarkable position for a small economy. For comparison, the 1996 outward stock of Belgium and Luxembourg (US \$ 73.3 billion), Denmark (US \$ 22.4 billion), Finland (US \$ 18.3 billion), Norway (US \$ 27.8 billion), Sweden (US $\$ 76.3$ billion) and Switzerland (US\$ 153.2 billion) are considerably smaller ${ }^{11}$. This is even more evident when we take the importance of outward FDI stock as a share of GDP into account $^{12}$. Although all European countries show a large and increasing importance of FDI, in case of the Netherlands, FDI as a percentage of GDP has increased from $31.1 \%$ in 1985 to as much as $43.2 \%$ in 1994 (OECD 1996, Chesnais and Sailleau 1997). Its closest follower is the UK, where FDI amounts to $26.4 \%$ of GDP in 1994. 
Table 6

\section{Stock of Dutch Outward FDI}

$1985,1990 \& 1995$

\begin{tabular}{lrrrrrr}
\hline & \multicolumn{2}{c}{1985} & \multicolumn{2}{c}{1990} & \multicolumn{3}{c}{1995} \\
\hline Country/ Region & Amount & Share & Amount & Share & Amount & Share \\
\hline European Union & 45362 & 34.2 & 86790 & 47.1 & 139078 & 49.2 \\
Austria & 1192 & 0.9 & 1425 & 0.8 & 2363 & 0.8 \\
Belgium/ Luxembourg & 10052 & 7.6 & 21245 & 11.5 & 37675 & 13.3 \\
Denmark & 626 & 0.5 & 1338 & 0.7 & 3206 & 1.1 \\
Germany & 12323 & 9.3 & 17579 & 9.5 & 22115 & 7.8 \\
Finland & 354 & 0.3 & 485 & 0.3 & 510 & 0.2 \\
France & 7198 & 5.4 & 14198 & 7.7 & 18568 & 6.6 \\
Ireland & 805 & 0.6 & 1170 & 0.6 & 5047 & 1.8 \\
Italy & 1797 & 1.4 & 2684 & 1.5 & 3861 & 1.4 \\
Spain & 2513 & 1.9 & 5708 & 3.1 & 9044 & 3.2 \\
Sweden & 418 & 0.3 & 631 & 0.3 & 3337 & 1.2 \\
UK & 7620 & 5.5 & 19049 & 10.3 & 31182 & 11 \\
Other EU & 463 & 0.3 & 1278 & 0.7 & 2170 & 0.8 \\
Other European & 8272 & 6.2 & 13269 & 7.2 & 23907 & 8.5 \\
Switzerland & 7619 & 5.8 & 12623 & 6.9 & 18964 & 6.7 \\
USA & 54343 & 41 & 54690 & 29.7 & 69759 & 24.7 \\
Japan & 1270 & 1 & 1749 & 0.9 & 2315 & 0.8 \\
Other countries & 23219 & 17.5 & 28672 & 15.6 & 47571 & 16.8 \\
Total & 132466 & 100 & 184170 & 100 & 282630 & 100 \\
\hline Source: Own & & & & & &
\end{tabular}

Source: Own calculations on basis of data supplied by the statistics department of De Nederlandsche Bank.

Table 6 gives details of the outward FDI stock from the Netherlands for three years, by destination. Two distinct patterns are noticeable, both of which are related. First of all, an extraordinary share (25\%) of Dutch FDI is directed towards the US. Although still growing in absolute numbers, the relative share of the US during this period declined from $41 \%$ in 1985 to $25 \%$ in 1995 (Narula and Hogenbirk 1999). This has been a result of a second pattern, notably, a refocusing of investments towards the European Union and other European countries. This trend is evident from the large share of total investments that the entire European Union had received by 1995: 49.2\% of Dutch outward FDI, growing from 34.2\% and 47.1\% in 1985 and 1990 respectively. Having a closer look at the European investments, we see a particular emphasis on a few European countries, most notably Belgium and Luxembourg, France, Germany, and the $\mathrm{UK}^{13}$. The share of FDI stock in other European (non-EU) countries has also increased, although much more modestly, from $6.2 \%$ in 1985 to $8.5 \%$ in 1995 . Much of this increase was directed to Switzerland whose share increased from $5.8 \%$ in 1985 to $6.7 \%$ of all Dutch outward FDI stock in 1995. 
The importance of investments in the US is still considerable. It remains the largest recipient country of Dutch outward FDI. Many Dutch firms have been engaging in M\&A activity in order to establish a base in the US. This trend is increasingly true for service MNEs (Hoesel and Narula 1999). Table 7 also shows the most important Dutch service MNEs that are currently active, broken down by financial and non-financial sectors. Amongst others, ING, ABN AMRO, Ahold and Aegon have been investing aggressively in the US to gain market share, particularly through M\&A activity ${ }^{14}$.

Although outward investments to Japan are about $1 \%$ of total outward investment stock, the strategic importance of these investments should not be underestimated (Belderbos 1999). A number of these investments are strategic asset-seeking in nature. Philips, for example, has tried to create closer links with the Japanese electronics manufacturing base to benefit from Japanese R\&D and manufacturing strengths. It has acquired stakes in three Japanese companies with important technological and design expertise and has set up a number of high technology joint ventures as well (Belderbos 1999).

In general, the share of Dutch investments that are directed to the Triad countries amounts to more than $82 \%$ in 1995. There has been no significant trend towards increasing importance of other (mainly developing) countries, whose share has been relatively stable for the 15 years preceding 1995.

Table 8 shows the importance of particular sectors in Dutch outward FDI. From the table we can see that the importance of the primary sector is almost negligible. The importance of the manufacturing sector is considerable, though declining from $87 \%$ in 1973 to $51 \%$ in 1995 . Unfortunately a lot of data are suppressed because they reveal confidential information of one particular firm. For those sectors where information is available we see that their importance has declined.

Table 7

Some of the most significant Dutch MNEs by industrial sector

\begin{tabular}{|c|c|c|c|c|}
\hline Name & Industry & $\begin{array}{r}\text { Dutch } \\
\text { Ranking }^{3} \text { by } \\
1995 \text { revenues }^{\#}\end{array}$ & $\begin{array}{r}1996 \\
\text { Revenues } \\
\text { (mln guilders) }\end{array}$ & $\begin{array}{r}\text { Rank in Fortune list } \\
1995\end{array}$ \\
\hline \multicolumn{5}{|c|}{ Manufacturing MNEs } \\
\hline Royal Dutch Shell ${ }^{2}$ & Petroleum \& refining & 1 & 215753 & 10 \\
\hline Unilever2 & Food and personal products & 2 & 87795 & 3.8 \\
\hline Philips & Electronics \& electrical equipment & 3 & 69195 & 23 \\
\hline Akzo & Chemicals & 8 & 22438 & 73.2 \\
\hline \multicolumn{5}{|l|}{ Nobel } \\
\hline KNP BT & Paper and packaging & 12 & 13637 & \\
\hline Heineken & Beverages & 15 & 12189 & \\
\hline DSM & Chemicals & 16 & 10263 & \\
\hline Reed-Elsevier ${ }^{2}$ & Printing and publishing & 19 & 8901 & \\
\hline Polygram & Music and entertaiment & 20 & 9488 & \\
\hline Hoogovens & Steel & 21 & 7933 & \\
\hline Stork & Machinery and eng. Services & 30 & 4916 & \\
\hline Wolters Kluwer & Printing and publishing & 28 & 4315 & \\
\hline Van Leer & Packaging & 32 & 4179 & \\
\hline
\end{tabular}




\begin{tabular}{|c|c|c|c|c|}
\hline Oce-van der Grinten & Photocopiers and printers & 39 & 4174 & \\
\hline CSM & Food products & 40 & 3026 & \\
\hline Gist Brocades & Biotechnology/ food additives & 47 & 2020 & \\
\hline Tulip & Computers & 94 & 532 & * \\
\hline Baan & Software & 109 & $348=$ & * \\
\hline \multicolumn{5}{|c|}{ Non-financial service MNEs } \\
\hline Ahold & Retail & 6 & 36538 & 185 \\
\hline SHV & Retail & 7 & 29963 & 230 \\
\hline KPN & Telecommunications & 10 & 20505 & 345 \\
\hline Vendex International & Retail & 14 & 12145 & \\
\hline KLM & Air transport & 17 & 10358 & \\
\hline Nedlloyd & Sea transport & 22 & 6831 & \\
\hline Pakhoed & Storage/transportation & 45 & 3594 & \\
\hline Randstad & Employment & 26 & 5953 & \\
\hline Heidemij (Arcadis) & Environmental engineering & 71 & 1066 & \\
\hline Van Ommeron & Storage/transportation & 72 & 880 & * \\
\hline \multicolumn{5}{|l|}{ Financial MNEs } \\
\hline ING & Insurance/banking & 4 & 47551 & 72 \\
\hline FORTIS1 & Insurance/banking & 5 & 40774 & 135 \\
\hline AEGON & Insurance/banking & 9 & 24487 & 307 \\
\hline ABN-AMRO & Banking & 11 & 19091 & 105 \\
\hline RABOBANK & Banking & 18 & 9647 & 297 \\
\hline
\end{tabular}

Sources: Revenues based on estimates from Het Financieel Dagblad: de omzetcijfers van 1996;

Jaarboek van Nederlandse ondernemingen 1995/96, Uitgeverij Tutein Nolthenius, 9th edition, and annual reports.

Fortune rankings from Fortune August 5, 1995, and July 30, 1990.

\# Dutch rankings based on Jaarboek van Nederlandse ondernemingen 1995/96, Uitgeverij Tutein Nolthenius, 9th edition. Adjusted for SHV (legally domiciled in the Netherlands Antilles, position 7) and Rabobank (not listed on the stock exchange, at position 18). This has moved all other companies down one or two positions.

1) Fortis is of joint Belgian and Netherlands nationality. 1996 revenues exclude MeesPierson.

2) Reed-Elsevier, Shell and Unilever are of joint British and Dutch ownership.

3) Dutch ranking list includes foreign-owned affiliates in the Netherlands.

* 1995 figures

Adapted from Hoesel and Narula (1999)

Table 8

Sectoral division of Dutch outward FDI Stock

(millions of guilders and share of total)

\begin{tabular}{|c|c|c|c|c|c|c|c|c|c|c|c|c|}
\hline & \multicolumn{2}{|c|}{$1973 \%$} & \multicolumn{2}{|c|}{$1975 \%$} & \multicolumn{2}{|c|}{$1980 \%$} & \multicolumn{2}{|c|}{$1985 \%$} & \multicolumn{2}{|c|}{$1990 \%$} & \multicolumn{2}{|c|}{$1995 \%$} \\
\hline PRIMARY & 127 & 0.3 & 137 & 0.3 & 439 & 0.5 & 125 & 0.1 & 193 & 0.1 & 176 & 0.1 \\
\hline Agriculture & 127 & 0.3 & 137 & 0.3 & 439 & 0.5 & 125 & 0.1 & 193 & 0.1 & 176 & 0.1 \\
\hline Mining and quarrying & & & & & & & .. & & .. & & .. & \\
\hline Oil & & & & & & & .. & & .. & & .. & \\
\hline SECONDARY & 38215 & 87 & 45577 & 85 & 72203 & 81 & 87925 & 66.3 & 103948 & 57 & 143938 & 51 \\
\hline Food, beverages and tobacco & 5863 & 13.3 & 6063 & 11.3 & 7103 & 7.9 & 11128 & 8.4 & 16326 & 8.9 & 27127 & 9.6 \\
\hline Textiles, leather and clothing & & & & & & & .. & & .. & & .. & \\
\hline Paper, printing and publishing & & & & & & & .. & & .. & & .. & \\
\hline Chemical products (1) & 20914 & 47.3 & 24918 & 46.5 & 45794 & 51 & 56486 & 42.6 & 59753 & 33 & 74796 & 27 \\
\hline Coal and petroleum products & & & & & & & .. & & .. & & .. & \\
\hline Non-metallic products & & & & & & & .. & & .. & & .. & \\
\hline Metal products (2) & 10634 & 24.1 & 13544 & 25.3 & 17394 & 19 & 18447 & 13.9 & 21855 & 12 & 28444 & 10 \\
\hline Mechanical equipment & & & & & & & .. & & .. & & .. & \\
\hline Electric and electronic equipment & & & & & & & .. & & .. & & .. & \\
\hline Motor vehicles & & & & & & & .. & & .. & & .. & \\
\hline Other transport equipment & & & & & & & .. & & .. & & .. & \\
\hline
\end{tabular}




\begin{tabular}{|c|c|c|c|c|c|c|c|c|c|c|c|c|}
\hline Other Manufacturing & 804 & 1.8 & 1052 & 2 & 1912 & 2.1 & 1864 & 1.4 & 6014 & 3.3 & 13571 & 4.8 \\
\hline TERTIARY & 5831 & 13 & 7847 & 15 & 17043 & 19 & 44481 & 33.6 & 78981 & 43 & 138515 & 49 \\
\hline Construction & 495 & 1.1 & 837 & 1.6 & 1189 & 1.3 & 1068 & 0.8 & 594 & 0.3 & 1986 & 0.7 \\
\hline Wholesale and retail trade & 2365 & 5.4 & 2890 & 5.4 & 6549 & 7.3 & 5489 & 4.1 & 12786 & 7 & 29587 & 11 \\
\hline Transport and storage (3) & 1312 & 3 & 1658 & 3.1 & 1491 & 1.7 & 1591 & 1.2 & 2701 & 1.5 & 4743 & 1.7 \\
\hline $\begin{array}{l}\text { Finance, insurance and business } \\
\text { serv. (4) }\end{array}$ & 1659 & 3.8 & 2462 & 4.6 & 7814 & 8.7 & 36333 & 27.4 & 62900 & 34 & 102199 & 36 \\
\hline Communication & & & & & & & .. & & .. & & .. & \\
\hline Other services (5) & & & & & & & .. & & .. & & .. & \\
\hline UNALLOCATED & & & & & & & .. & & .. & & .. & \\
\hline TOTAL & 44173 & 100 & 53561 & 100 & 89685 & 100 & 13253 & 100 & 183122 & 100 & 282629 & 100 \\
\hline
\end{tabular}

Source: De Nederlandsche Bank, unpublished data.

1. Up to 1992, including mining and quarrying, oil and chemicals.

2. Up to 1992 , including metal and electrical engineering.

3. Up to 1992, including transport, storage and communication.

4. Up to 1992, including other services. As from 1993, including real estate activities.

5. Including electricity, gas, water, hotels, restaurants and other services.

Adapted from Hoesel and Narula (1999)

The share of food, beverages and tobacco in total has declined from 13\% in 1973 to $10 \%$ of total outward investments in 1995. The chemical industry contributed $47 \%$ of all outward stock in 1973, but its share has declined considerably to no more than $27 \%$ in 1995 . A similar trend is clear for the metals industry. Its share in total has declined from $24 \%$ in 1973 to $10 \%$ in 1995 . The decline in the manufacturing sector is compensated by an increasingly important services sector. Its share in total outward FDI has increased from $13 \%$ in 1973 to $49 \%$ in 1995 . The largest increase is visible within the finance, insurance and business services segment.

Just a few MNEs account for a large share of all outward investment. The Netherlands is home to a number of large manufacturing MNEs: Royal Dutch Shell, Philips, Unilever, DSM, and Akzo-Nobel (see Table 7). Together they account for $16 \%$ of all employment, although this share continues to decline. Their share in industrial R\&D is considerable and amounts to 47\% of all business R\&D in 1994 (declining from 70\% in 1969) (Minne 1997). The MNEs listed in Table 7 dominate Dutch outward investment. In 1985, the 10 largest firms dominated more than 75\% of all outflows (Nieuwkerk and Sparling 1985). Naturally, this situation makes the outflow of investments to a large extent dependent on the developments within those particular firms.

Van Den Bulcke (1983) draws attention to the fact that Dutch MNEs are also considerably more internationalised than those of other European countries. He shows that Dutch MNEs employ three times as many workers in affiliates outside the Netherlands than in the domestic affiliates. This pattern has continued into the 1990s. Calculations on the basis of UN data (1997) show that the 3 largest Dutch MNEs: Royal Dutch Shell (listed on the $1^{\text {st }}$ place of the 100 largest MNEs for the $5^{\text {th }}$ consecutive year), Unilever (ranking 
$17^{\text {th }}$ ), and Philips (ranking $18^{\text {th }}$ ), realise more than $70 \%$ of their sales abroad. Foreign employment amounts to more than $80 \%$ of total and foreign assets are at least $65 \%$ of total.

Royal Dutch Shell is considerably more internationalised than its closest followers in the oil sector, the US firm Exxon (ranking $4^{\text {th }}$ ) and the French firm Elf Aquitaine SA (ranking $14^{\text {th }}$ ) whose shares of foreign assets in total amounts to $66.7 \%$ and $26.9 \%$ respectively. Their shares of foreign sales, and employment in total amount to $96.9 \%$ and $53.7 \%$ for Exxon and $27.8 \%$ and $47.5 \%$ for Elf.

\section{Inward FDI}

The Dutch inward investment position is also extraordinary. The Netherlands ranks $8^{\text {th }}$ following the US, the UK, Germany, China, France, Canada, and Australia, with total inward FDI stock amounting to US\$ 118.6 billion in 1996 (United Nations 1997). Although considerably smaller than outward FDI, inward stock still amounts to $31 \%$ of GDP in 1995.

The motivations for locating investments in the Netherlands are changing. During the 1950, the main attraction was relatively cheap labour due in part to stringent government policy. However, the focus has gradually changed over time. The Netherlands Foreign Investment Agency (NFIA), increasingly emphasises many of the other favourable aspects of the Netherlands. One of the most important location advantages is the Netherlands' favourable location in Europe (the "Gateway to Europe"). Within a 500-kilometre radius of Amsterdam a firm can reach a potential market of 170 million people, almost $46 \%$ of the entire European population. It is therefore not surprising that the importance of other European countries for the Dutch economy is considerable and growing. Moreover, investments are further stimulated by the increased regionalisation within the European Union (EU).

Other important L-advantages of the Netherlands include the experience and know-how of a centuries-old tradition of international trading, the multi-lingual population, the high-skilled and flexible labour force, political stability, non-discriminatory fiscal policy, and a favourable investment climate (NFIA 1997a, 1997b). Furthermore, foreign companies can benefit from a virtual absence of exchange controls. Foreign companies have the same status as Dutch and can benefit from an array of incentives for new investments, high technology projects, and energy and environmental projects.

The NFIA also likes to characterise the country as Europe's logistics centre and uses phrases such as "Nederland, distributieland", to emphasise the importance of trade and distribution, the advanced infrastructure, and the highly developed logistics service sector. Furthermore, Dutch customs has a reputation for being flexible, co-operative and innovative. Although it is generally assumed that inward FDI in distribution activities results in few direct employment effects, the government expects that they will have 
considerable indirect effects and therefore they are an important point on the agenda. Indeed, given the considerable strength of Dutch MNEs in transportation, distribution and logistics, the presence of inward FDI helps to bolster the domestic firms too. Again the favourable location in Europe matters, and the strong infrastructural facilities (among which the favourable warehousing system ${ }^{15}$ ) encourage these activities.

One particular aspect of inward investments cannot be ignored. The Netherlands is a popular location for foreign holding companies. They can benefit from the many tax treaties to which the Netherlands is party (Kox and Velzen 1985) and thereby reduce the actually amount of taxes that has to be paid. Many firms use a combination of holding companies in both the Netherlands and the Dutch Antilles (another attractive location for holding companies), to exploit the even more favourable taxing system there.

Table 9 gives details of the Dutch inward FDI stock by destination for four points in time: $1973^{16}, 1983$, 1989 and 1995. We can distinguish 2 distinct periods. First of all from 1973 up to 1985, during which the total stock of outward FDI more than doubled to Dfl 52 billion. Several studies during this period have evaluated different aspects of inward FDI (Jong and Mare $1984^{17}$, Loeve $1984^{18}$, Buck $1985^{19}$, Nieuwkerk and Sparling $1985^{20}$ ). Although different in approach, these studies generally have similar conclusions. The most important findings are summarised in Table 10, and suggest that a large proportion of inward investments took place in the period 1960-1973. A large share originates in the US, initially stimulated by the Marshall-plan. Although growing in absolute numbers, the relative share of the US during this period declined slightly from 37\% in 1973 to 35\% in 1983. Dunning (1992) has shown that such investments are primarily encouraged by the superior ownership advantages of US firms, and their tendency to invest in faster growing industries, more particularly aiming at sectors that supply high technology products.

Furthermore, although the share of the EU declined from 43\% in 1973 to 32\% in 1983, intra-European investments remained significant. During this period, Germany and the United Kingdom were the largest European investors, although the German investments have declined considerably from $12.7 \%$ of total in 1973, to 5.5\% in 1983. The investments from the UK and Belgium and Luxembourg also showed a slight decrease. Investments from other European (non-EU) countries, primarily from Switzerland, marginally increased in importance over this period, from $10 \%$ in 1973 to $11 \%$ in 1983.

At the same time we see the emergence of investments by Japanese firms from just $1 \%$ in 1973 to $2.5 \%$ of total in 1983. During this period Japanese firms started internationalising and therefore their foreign share of all production was still considerably smaller than that of other countries.

The share of developing countries increased considerably from 5.8\% in 1973 to over $16 \%$ in 1983 . With the exception of the African countries, most developing countries increased their activities in the Netherlands but the most important increase occurred from Asian and Latin American investors. 
Table 9

\section{Stock of inward FDI}

(million Dfl)

\begin{tabular}{lrrrrrrrr} 
& 1973 & & 1983 & & 1989 & & $1995 *$ \\
\hline Country/ Region & Amount & Share & Amount & Share & Amount & Share & Amount & Share \\
\hline European Union & 8840 & 42.8 & 16319 & 31.5 & 43629 & 41.4 & 89929 & 49.9 \\
Belgium/ Luxembourg & 1514 & 7.3 & 2600 & 5.0 & 10516 & 10.0 & 23425 & 13.0 \\
Denmark & 11 & 0.1 & 157 & 0.3 & 464 & 0.4 & 1678 & 0.9 \\
Germany & 2614 & 12.7 & 2875 & 5.5 & 8818 & 8.4 & 13768.4 & 7.6 \\
France & 934 & 4.5 & 2386 & 4.6 & 3823 & 3.6 & 3561.9 & 2.0 \\
Ireland & 22 & 0.1 & 219 & 0.4 & 651 & 0.6 & 4830.7 & 2.7 \\
Italy & 73 & 0.4 & 162 & 0.3 & 129 & 0.1 & 691 & 0.4 \\
UK & 3672 & 17.8 & 7920 & 15.3 & 19060 & 18.1 & 22943 & 12.7 \\
Switzerland & 2039 & 9.9 & 5670 & 10.9 & 11126 & 10.6 & 17878 & 9.9 \\
USA & 7689 & 37.2 & 18020 & 34.7 & 26702 & 25.4 & 37476 & 20.8 \\
Japan & $\mathrm{N} . \mathrm{A}$. & 0.7 & 1291 & 2.5 & 3870 & 3.7 & 7810 & 4.3 \\
Other developed & 731 & 3.5 & 2051 & 4.0 & 6121 & 5.8 & N.A. & N.A. \\
Developing & 1201 & 5.8 & 8514 & 16.4 & 13853 & 13.2 & N.A. & N.A. \\
Total & 20659 & 100 & 51865 & 100 & 105318 & 100 & 180147.0 & 100 \\
\hline Source Van Nieuwkerk
\end{tabular}

Source: Van Nieuwkerk and Sparling, 1985; DNB Quarterly Bulletin, various issues

N.A.= not available

$*=1995$ stocks are own estimates on the basis of flow data reported by DNB.

The second period runs from 1983 to 1995, during which years the total inward stock increased almost fourfold to Dfl 180 billion, and investment behaviour was characterised by a large increase in the importance of intra-European investments ${ }^{21}$. This seems to confirm the view that MNEs started realising the full potential of further European unification in the mid-1980s, and commence a period of restructuring within Europe (Dunning 1997a, 1997b). A consequence of this was a growing share of EU inward FDI activities in the Netherlands, which reached $50 \%$ by 1995. The share of the UK, Belgium and Luxembourg, and Germany in Dutch inward FDI increased considerably. Swiss outward stock remained considerable at around $10 \%$ of total.

\section{Table 10}

\section{Summary of the most important findings of studies on inward FDI in the Netherlands}

(all studies analyse the situation up to 1984)

\begin{tabular}{|l|l|}
\hline Investing nations & $\begin{array}{l}\text { US (although its share in total investments is gradually declining) } \\
\text { Europe (Germany, the United Kingdom, and Belgium) } \\
\text { An important new-comer is Japan }\end{array}$ \\
\hline Date of establishment & Mainly during the economic boom in the 1960s and early 1970s
\end{tabular}




\begin{tabular}{|l|l|} 
& $\begin{array}{l}\text { The decline after 1973 is due to economic slow-down, } \\
\text { increasing wage levels and high inflation }\end{array}$ \\
\hline Mode of entry & $\begin{array}{l}\text { Mainly greenfields (up to 70\%) } \\
\text { The share of take-overs is less than 25\% } \\
\text { Joint ventures are just 5\% of all ventures }\end{array}$ \\
\hline Sectoral distribution & $\begin{array}{l}\text { Since the end of the 1950s we can see a decline in manufacturing FDI. } \\
\text { By } 1984 \text { only 23\% of all foreign activities is in the manufacturing sectors. } \\
\text { More and more FDI is oriented towards trade and distribution. } \\
\text { There is also increasing importance of the (business) services sector, } \\
\text { since the beginning of the 1970s }\end{array}$ \\
\hline $\begin{array}{l}\text { Manufacturing } \\
\text { investments }\end{array}$ & $\begin{array}{l}\text { Companies originating in different countries have different target sectors } \\
\text { within the Netherlands. UK firms emphasise chemicals, } \\
\text { Swedish firms metals, machinery, and paper. } \\
\text { German firms target machinery. } \\
\text { US firms establish subsidiaries in the chemical and electronics sector }\end{array}$ \\
\hline $\begin{array}{l}\text { Locational factors } \\
\text { influencing the choice } \\
\text { for the Netherlands }\end{array}$ & $\begin{array}{l}\text { Favourable location in Europe, good infrastructure (harbour and airport), } \\
\text { favourable fiscal conditions, labour market }\end{array}$ \\
\hline $\begin{array}{l}\text { Contribution to Dutch } \\
\text { employment }\end{array}$ & Considerable \\
\hline
\end{tabular}

Source: Buck (1985), Jong and Mare (1984), Loeve (1984, 1986), Nieuwkerk and

Sparling (1985).

Furthermore, US investments still play a considerable role. Although they continued to grow in absolute numbers, the relative share of the US during this second period declined slightly from $25 \%$ in 1989 to $21 \%$ in 1995. Dunning (1992) emphasises that during the period after 1985 US investments have been encouraged by the expected positive results from further unification within Europe. The US investments have taken place in sectors that are expected to be influenced by the EU 1992 provisions, such as pharmaceuticals, motor vehicles, finance (except banking), and business services.

Table 11

Largest foreign firms in the Netherlands, 1996

\begin{tabular}{lllr}
\hline Company & Home economy & Industry & Sales (mln dfl) \\
\hline Industrial & & & \\
Exxon Nederland & United States & Petroleum & 8854 \\
Sara Lee/DE & United States & Food & 8358 \\
Cargill Nederland & United States & Food & 7075 \\
Dow Benelux & United States & Chemicals & 5218 \\
Ballast Nedam & United Kingdom & Construction & 3825 \\
Texaco Nederland & United States & Petroleum & 3700 \\
BP Nederland & United Kingdom & Petroleum & 2478
\end{tabular}




\begin{tabular}{lllr} 
IBM Nederland & United States & Computers & 2309 \\
Siemens Groep & Germany & Electronics & 2276 \\
Kuwait Petroleum (Nederland) & Kuwait & Petroleum & 1797 \\
DuPont de Nemours (Nederland) & United States & Chemicals & 1749 \\
Daimler-Benz Holding Nederland & Germany & Automobiles & 1540 \\
BASF Nederland & Germany & Chemicals & 1461 \\
Nestlé Nederland & Switzerland & Food & 1386 \\
& & & \\
Finance and Insurance & & & Assets (mln \\
& & dfl) \\
Bank of Tokyo-Mitsubishi & Japan & Banking & 4385 \\
(Holland) & & & \\
Banque Paribas Nederland & France & Banking & 7460 \\
Dai-Ichi Kangyo Bank Nederland & Japan & Banking & 5332 \\
F. van Lanschot Bankiers & United Kingdom & Banking & 11663 \\
Indover Bank (31/03/97) & Indonesia & Banking & 5468 \\
Tokai Bank Nederland & Japan & Banking & 1800 \\
Yamaichi Bank Nederland & Japan & Banking & 1270 \\
\hline
\end{tabular}

Source: Het Financieele Dagblad, Omzetcijfers, 1997

Japanese investors were also primarily motivated by the continuing trend towards European Unification. Many Japanese firms used the Netherlands as a base for their distribution activities in Europe (Belderbos 1999) and have established European headquarters in the Amsterdam Area (see KPMG 1993). The rise of Japanese investments has continued, resulting in a 4.3\% share in total inward FDI by 1995. The importance of developing countries slightly decreased to $13.2 \%$ in 1989.

The importance of the intra-European, US, and Japanese investments is visible not just from the actual value of the investments, but also from the actual number of firms that have located in the Netherlands. In total, more than 6700 foreign companies currently have establishments in the Netherlands (NFIA 1997a). Buck Consultants International have reported the presence of 3886 European firms in the Netherlands, compared to 1833 American ones, and 457 Japanese in 1996 (mentioned in NFIA 1997b). Table 11 lists the most important foreign investors in the Netherlands by 1996. Some of the large US investors include Dow Chemical, Du Pont de Nemours, Eastman Chemicals, General Electric Plastics, Cargil, Philips Morris, Packard Bell, and Mobil Chemical Co. The Japanese firms primarily include banks such as Tokai Bank Nederland and Bank of Tokyo-Mitsubishi (Holland). Among the large European investors are the German firms Siemens, Daimler-Benz, and BASF; Nestlé from Switzerland, and the UK firm British Petroleum (BP).

\section{CONCLUSIONS}


Although the precise role of economic globalisation on competitiveness of countries has been varied, generally, its effect on the industrialised economies has been towards a convergence of income levels and consumption patterns, and a growing interdependence of these economies. It has also been noted, both here and elsewhere (see e.g., Freeman and Lundvall [eds.] 1988, Bellak and Cantwell 1997, and other chapters in this volume), that globalisation has influenced small countries to a greater extent than larger countries. This is because, inter alia, by virtue of their size, they tend to be more internationalised than their larger counterparts, and have a much more limited set of resources available to them. This internationalisation takes many forms, but in general, small countries are more deeply involved in international trade and investment than other countries, both as a source of assets due to their limited resources, as well as a way to seek economies of scale, due to their size.

One of the hallmarks of globalisation has been the role of the MNE, as cross-border economic activity has continued to grow. The MNE has become pivotal in economic growth and development through its overseas production, its intra-firm and inter-firm trading activities, and other forms of cross-border economic activity. It comes as no surprise, therefore, that the role of MNEs in small countries is also significant and growing. In this chapter, our attention is focused on the case of the Netherlands, which in some ways represents a typical small country, given its resources and size, but in many other ways, particularly the extent and nature of its international activities, it is very much an exception to the 'average' small country. We elucidate.

First, it is home to the sixth largest outward FDI stock in the world, which was estimated (on a historical cost basis) at US\$ 184.7 billion in 1996. This is dominated by a small group of very large conglomerates, which are amongst the most internationalised in the world. Not only is their role in outward FDI from the Netherlands quite significant, so is their influence of exports and imports. In addition, they play a considerable part in domestic economic activity, particularly employment and R\&D activity. The pattern of its outward FDI has become increasingly concentrated within the Triad, particularly towards the US, and the EU. Although its investments in Japan continue to be small in value, they have considerable strategic importance.

Second, it is one of the most important destinations for inward FDI activity. Inward FDI has also demonstrated a similar pattern as outward FDI. The Netherlands is also one of the most important destinations for inward FDI in Europe. Within these observed trends, there has been an increasing concentration of both inwards and outward FDI (in addition to trade) to and from other EU countries. This intra-EU trend is associated with the process of the single European market initiative, and the nature and extent of its inward FDI starkly illustrate this. Indeed, its location advantages as a destination for inward FDI are a function of its de facto market size, given its central location within the EU and its well 
developed infrastructure. This is reflected in the importance of the Netherlands as a prime location for European-wide distribution services. In addition, the growing competitiveness of the service sector in the Netherlands plays a pivotal role. Dutch service companies have been internationalising rapidly, especially in transportation, distribution, banking and insurance. This represents an important L advantage for the Netherlands.

What are the implications for other small economies? It is axiomatic that small countries are affected by economic globalisation to a greater extent than larger economies, and in general, they have taken a pragmatic view to this. It is, however, even more crucial for small countries to invest in improving their competitiveness, since their activities are concentrated in a few sectors. As such, there is less leeway in delaying the termination of 'sunset' industries, or indeed, in the adoption of new technologies and the upgrading of their created assets to enter new and emerging sectors. They are also more susceptible to errors of judgement: if a small country selects the 'wrong' sector to develop and build up competencies in, or underinvests in these industries in such a way that they are unable to compete effectively on world markets, there is no home market to soften the shock. The ramifications to the rest of the economy of poor industrial policy can be significant, and even systemic. The limited industrial distribution means that, what in a large country might be a small mistake relative to the size of the economy, would in a small country be a major one. At the same time, small countries such as the Netherlands are beleaguered by increased competition for FDI in a globalising world, and the need to maintain and upgrade their location advantages in response to changing economic realities is central to their survival. 


\section{REFERENCES}

Ark, B. van, and H.J. de Jong (1996) "Accounting for Economic Growth in the Netherlands since 1913", Economic and Social History in the Netherlands, Vol. 7, pp. 199-242.

Beije, P. and O. Nuys (1997) How Institutional is the Diamond? A Critical Analysis of Porter with Regard to Small Countries, Erasmus University Management Report, No. 51.

Belderbos, R. (1999, forthcoming) "Dutch Multinationals in Japan”, in Hoesel, R. van and R. Narula (eds) Multinational Enterprises from the Netherlands, London: Routledge.

Bellak, C. and Cantwell, J. (1998) "Globalization tendencies relevant for latecomers: some conceptual issues", in M. Storper, S. Thomadakis and L. Tsipouri (eds) Latecomers in the Global Economy, London: Routledge, pp 40-75.

Boeckhout, I.J., B.M. Verhoeff and A.C.P. Vester (1987) "De Randstad als vestigingsplaats voor internationaal georienteerde bedrijvigheid", Economische en Statistische Berichten, 2-12-1987.

Bouma, E (1996) "Foreign Direct Investments" in Jepma, C.J. and A.P. Rhoen (eds.) International Trade. A Business Perspective, London: Longman.

Brouthers, K.D. and L.E. Brouthers (1997) "Explaining National Competitive Advantage for a Small European Country: a Test of Three Competing Models", International Business Review, Vol. 6, N. 1, pp. 53-70.

Buck, R. (1985) Nieuwe Japanse en Amerikaanse industriele vestigingen in west-Europa, Nijmegen. Buckley, P.J., C.L. Pass and K. Prescott (1992) "The Internationalization of Service Firms: A Comparison with the Manufacturing Sector", Scandinavian International Business Review, Vol. 1, No. 1, pp. 39-56.

Bulcke, D. Van Den (1983) "Multinationale ondernemingen en de Europese Gemeenschap: impact en respons", Maandschrift Economie, Jaargang 47, pp. 304-326.

Central Bureau of Statistics (1995) Statistical Yearbook.

Chesnais, F. and A. Sailleau (1997) The Pattern of Foreign Direct Investment in Europe: What Can We Learn from the Balance of Payments Data, CEDIpaper, mimeo.

Chesnais, F. (1992) "National Systems of Innovation, Foreign Direct Investment and the Operations of Multinational Enterprises", in B.A. Lundvall (ed) National Systems of Innovation. Towards a Theory of Innovation and Interactive Learning, London: Pinter.

Dicken, P. and M. Quevit (1994) Transnational Corporations and European Regional Restructuring, Netherlands Geographical Studies.

Dunning, J.H. (1981) International Production and the Multinational Enterprise, London.

Dunning, J.H. (1988) Explaining International Production, London: Unwin Hyman.

Dunning, J.H. (1992) "Trans-Atlantic Foreign Direct Investment and the European Community", International Economic Journal, Vol. 6, No. 1, pp. 59-82.

Dunning, J.H. (1993a) Multinational Enterprises and the Global Economy, Wokingham: AddisonWesley.

Dunning, J.H. (1993b) The Globalisation of Business. The Challenge of the 1990s, London: Routledge. Dunning, J.H. (1994) "Reevaluating the Benefits of Foreign Direct Investment", Transnational Corporations, Vol. 3, No. 1, pp. 23-51.

Dunning, J.H. (1997a) “The European Internal Market Programme and Inbound Foreign Direct Investment, Part I”, Journal of Common Market Studies, Vol. 35, No. 1, pp. 1-30.

Dunning, J.H. (1997b) “The European Internal Market Programme and Inbound Foreign Direct Investment, Part II", Journal of Common Market Studies, Vol. 35, No. 2, pp. 189-223.

Dunning, J.H. and R. Narula (eds) (1996) Foreign Direct Investment and Governments: Catalysts for Economic Restructuring, London: Routledge.

Freeman, C. and B-A.Lundvall (eds) (1988) Small Countries Facing the Technological Revolution, London: Pinter. 
Freeman, C. and C. Perez (1988) "Structural Crisis of Adjustment, Business Cycles and Investment Behaviour", in Dosi, G. et al (eds) Technical Change and Economic Theory, London: Pinter.

Hamel, G. and C.K. Prahalad (1994) Competing for the Future, Boston, Massachusetts: Harvard

Business School Press.

Hoesel, R. and R. Narula (eds) (1999 forthcoming) Multinational Enterprises from the Netherlands, London: Routledge.

Jacobs, D. , P. Boekholt and W. Zegveld (1990) De economische kracht van Nederland, Utrecht:

Stichting Maatschappij en Onderneming (SMO).

Jacobs, D. and M.W. de Jong (1992) "Industrial Clusters and the Competitiveness of the Netherlands.

Empirical Results and Conceptual Issues", De Economist, Vol. 140, No. 2, pp. 233-252.

Jong, J.W. de and J.T. de Mare (1984) Multinational Enterprises and the Structure of the Dutch

Economy, UvA Research Memorandum No. 8415.

Kox, H. and L. van Velzen (1985) Kapitaalexport vanuit Nederland, Amsterdam: Stichting Onderzoek Multinationale Ondernemingen (SOMO).

KPMG (1993) The 1992 Survey of Foreign-based Companies in the Amsterdam-Area, Amsterdam. Loeve, A. (1984) Internationale ondernemingen in Nederland. Omvang en lokatie van vestigingen in Nederland, StePro-rapport, no. 30a, Utrecht: Geografisch Instituut.

Loeve, A. (1986) "Buitenlandse ondernemingen in Nederland", ESB, 26-2-1986.

Minne, B. (1997) "International Battle of Giants. The Role of Investment in Research and Fixed Assets", Research Memorandum Central Planbureau, no. 36, The Hague.

Narula, R. (1996a) Multinational Firms, Technology, and Economic Activity: An Agenda for Research, paper prepared for TSER Workshop in Rome, 30 May - 1 June 1996.

Narula, R. (1996b) Multinational Investment and Economic Structure. Globalisation and

Competitiveness, London: Routledge.

Narula, R. and J.H. Dunning (1998) Globalisation and New Realities for MNE-Developing Host County Interaction, MERIT Research Memorandum, 2/98-015.

Narula, R. and A.E. Hogenbirk (forthcoming 1999) Dutch Manufacturing Investments in the United States: 1950-1995, in Hoesel, R. van and R. Narula (eds) Multinational Enterprises from the

Netherlands, London: Routledge.

NFIA (1997a) A Guide: Investment in the Netherlands, The Hague.

NFIA (1997b) The Netherlands. Europe's logistics center. 15 cases, The Hague.

Nieuwkerk, M. van and R.P. Sparling (1985) De internationale investeringspositie van Nederland,

Monetaire Monografieen, No. 4, Deventer: Kluwer.

OECD (1996) Economic Survey, the Netherlands.

OECD (1998) Economic Survey, the Netherlands.

Porter, M.E. (1990) The Competitive Advantage of Nations, New York: Free Press.

Porter, M.E. (1994) "The Role of Location in Competition", Journal of the Economics of Business, Vol. 1, No. 1, pp. 35-39.

Rodrik, D. (1997) Has Globalization Gone Too Far? Institute for International Economics, Washington, D.C.

Ruigrok, W. and R. van Tulder (1995) The Logic of International Restructuring, London: Routledge. Saeger, S. (1997) "Globalization and deindustrialisation: myth and reality", Weltwirtschaftliches Archiv, Vol. 133, pp 579-607

Schuurman, P. and J.P. Huner (1996) Internationale Investeringen. Discussienota, Den Haag:

Directoraat-Generaal voor de Buitenlandse Economische Betrekkingen.

Schwartz, H. (1994) States versus Markets. History, Geography and the Development of the

International Political Economy, New York: St. Martin's Press.

Tulder, R. van (1999)

United Nations (1993) World Investment Report 1993, New York. 
United Nations (1995) Handbook of International Trade and Development Statistics, New York. United Nations (1997) World Investment Report 1997, New York.

Walsh, V. (1988) "Technology and the Competitiveness of Small Countries: A Review, in Freeman, C. and B-A. Lundvall (eds) Small Countries Facing the Technological Revolution, London: Pinter.

Went, R. (1996) Grenzen aan de globalisering?, Amsterdam: Het Spinhuis.

Zanden, J.L. van (1997) Een klein land in de 20e eeuw, Utrecht: Het Spectrum. 


\section{NOTES}

${ }^{1}$ There are many criteria on which one can classify the size of a country. Some of them are population, national income, geographical area, availability of various natural resources, technological level, rate of growth, and degree of dependency on other countries (Walsh 1988).

${ }^{2}$ We follow the OECD definition that considers FDI to be an investment conducted with a view of establishing a lasting financial relationship between the investor and the enterprise concerned whereby the investor obtains, maintains, or expands significant influence on the management of the enterprise.

${ }^{3}$ See Narula and Dunning (1998) for a fuller discusssion of these issues.

${ }^{4}$ See Freeman and Lundvall (eds) (1988).

${ }^{5}$ On an absolute scale - although the expenditure on R\&D as a percentage of GDP of, say, Sweden is higher than that of the U.S (3\% vs. 2.6\%), in absolute terms its R\&D expenditures are just $3.9 \%$ that of the U.S. (Freeman and Hagedoorn 1992).

${ }^{6}$ Its closest competitors in Europe are Antwerp, Marseille, Hamburg, Le Havre, and Amsterdam that all handle maximum $1 / 3$ of the goods handled in Rotterdam (NFIA 1997). Its largest competitor worldwide is the harbour in Singapore.

${ }^{7}$ Zanden (1996) shows that most other small European countries have actually specialized during this period. Denmark concentrated on specific agricultural products. Norway developed both its fishery and shipping industries.

8 The Northwest European countries include Austria, Belgium, Denmark, Finland, France, Germany, Netherlands, Norway, Sweden, Switzerland and the UK (Ark and Jong, 1996).

${ }^{9}$ In most other countries, the importance of trade is actually increasing rapidly (Dunning 1993b).

${ }^{10}$ The Dutch Bank started the registration of investment flows after W.W. II. The registration is based on balance of payment data. They are likely to give a serious underestimation of the actual investment stock since they do not take sequential investments, made with reinvested profits, into account.

${ }^{11}$ See also Hoesel and Narula (1999), Table 1.9.

${ }^{12} \mathrm{We}$ are aware that we are comparing a stock figure (FDI) with a flow figure (GDP). However, it is well accepted that sales of MNEs are a monotonic function of FDI stock. Therefore we can use sock as an indicator for sales. Furthermore, sales are an indicator of value-added. We therefore think the comparison of FDI stock with GDP gives an good indication of the importance of FDI in the economy.

${ }^{13}$ A similar pattern has been shown by Chesnais and Sailleau (1997) who used OECD data for their analysis.

${ }^{14}$ For further details, see Hoesel and Narula (1999). 
15 Foreign firms that have distribution activities in the Netherlands can benefit from a variety of warehouse arrangements, including public and private bonded warehouses, merchant-controlled bonded warehouses, and Type-E bonded warehouses. A classic warehouse has approved buildings, is under Customs supervision (double locks) and has Customs documents covering both storage and removal of goods. More than 20 years ago Dutch Customs decided to change this procedure. Wanting to reduce physical Customs control, it was decided to maintain control by means of more specific storage documents and more demands on the records of the company concerned, if necessary combined with security. They created the "fictitious warehouse controlled by means of the commercial administration of the company concerned", or Type-E bonded warehouse (NFIA 1997b). Firms can obtain a license for this kind of warehousing.

${ }^{16}$ When the UK along with Ireland and Denmark joined the EU.

${ }^{17}$ De Jong and de Mare (1984) analyse the relationships between MNEs and the structure of the Dutch economy. They use data from the Dutch Central Bureau of Statistics (CBS).

${ }^{18}$ Loeve (1984) conducted a questionnaire study covering 1851 majority-owned affiliates. His results are also presented in Loeve (1986). His main emphasis is on the geographical spread of those investments.

19 Buck (1985) analyses the importance of start-ups of U.S. and Japanese MN-affiliates in Western Europe.

${ }^{20}$ Van Nieuwkerk and Sparling (1985) have conducted a thorough analysis of the balance of payments data collected by the Dutch Central Bank (DNB).

${ }^{21}$ During this period there is less scholarly interest in Dutch inward FDI, and thorough studies are lacking. This is surprising since by 1992, as in 1980, the Netherlands was ranked on a seventh place of receiving countries (Schuurman and Huner, 1996). 